\title{
Bilateral Severe Vitritis, an intraocular recurrence of B cell lymphoma: A case report.
}

\author{
Vitritis severa bilateral, una recurrencia intraocular de linfoma de células B: \\ reporte de caso.
}

\author{
Ming Chen ${ }^{1} \&$ John H Drouilhet ${ }^{1}$.
}

Chen, M. \& Drouilhet, J.H. Bilateral Severe Vitritis, an intraocular recurrence of B cell lymphoma: A case report. Int. J. Med. Surg. Sci., 4(4):1241-1244, 2017.

SUMMARY: Purpose: To report a case of bilateral vitritis originated from Primary Central Nervous System Lymphoma. Diagnosis was made from a careful history taking and confirmed with vitrectomy. Case report: 65-year-old Vietnamese male had one month of progressive blurred vision in both eyes without other eye complaint. History revealed that about one year previously, he was diagnosed with primary diffuse large B cell lymphoma. He was treated with chemotherapy of Methotrexate $3.5 \mathrm{~g} / \mathrm{m}^{2}$ and cytarabine $2 \mathrm{mg} / \mathrm{m}^{2}$, and a whole brain radiation therapy. There was a complete remission after the therapy. Fundus of both eyes was partly obscured by cells mainly in the posterior vitreous. Sequential bilateral vitrectomies were done on 5/1/17 and 7/17/17 without complication. The vitreous sample from the first eye having vitrectomy was sent for study which demonstrated large B cell lymphoma. Postoperative vision improved to 20/25 both eye without the complaint of hazy vision. Conclusion: Good history taking assisted in the diagnosis of intraocular lymphoma in this case with bilateral vitritis. However, bilateral vitrectomy restored the vision and further confirmed the diagnosis of lymphoma for future follow up care.

KEYWORDS: large B cell lymphoma; intraocular lymphoma; central nervous system Iymphoma; vitritis; uveitis.

\section{INTRODUCTION}

Primary central nervous system lymphoma (PCNSL) accounts for 4 to $7 \%$ of brain tumors. The onset of this lymphoma is generally in the 5th and 6th decade of life. Primarily involves the brain, eyes, and leptomeninges without other systemic findings. It occurs mostly in the immunosuppressed population but its incidence has increased in normal patients as well such as this patient (Chan \& Wallace, 2004; Hormigo \& De Angelis, 2003; Smith et al., 2000). The most common ophthalmic manifestations are posterior uveitis or vitritis, combined anterior and posterior uveitis, or subretinal pigment epithelial infiltrates (Hochberg \& Miller, 1988). The anterior or posterior uveitis in $75 \%$ of patients and sub retinal pigment epithelium (RPE) infiltrates in $20 \%$ of patients. Sub RPE infiltrates from accumulation of lymphocytes may be intermittently present leaving geographic atrophy on resolution. The appearance of ischemic retinopathy or optic neuropathy is from accumulation of lymphocytes around the retinal vessels.
If the patient with uveitis has a negative or partial response to steroids, then one should consider samples from the aqueous and or vitreous should be done for cytology and complete diagnostic testing. Other tests such as Immunophenotyping to determine clonality sharing same surface light chain, gene rearrangement to identify clonality within the cells, neuroimaging and cerebrospinal fluid study should be done.

Chemotherapy such as rituximab, a chimeric antibody, induces apoptosis in CD20 positive cells-B cells. Intravitreal methotrexate and/or rituximab with or without vitrectomy are indicated treatment of the vitritis. The five-year survival rate ranges from less than $20 \%$ to $34 \%$ with the best therapy (Panageas et al., 2005; DeAngelis et al., 2002). The differential diagnosis between chronic inflammation and intraocular lymphoma become very difficult (Wilson et al., 1992). The suspicion of a masquerade syndrome, particularly a primary CNS lymphoma, should always be considered in the elderly like this case (Zamiri et al., 1997).

1. University of Hawaii, John A Burns School of Medicine, USA. 
Chen, M. \& Drouilhet, J.H. Bilateral Severe Vitritis, an intraocular recurrence of B cell lymphoma: A case report. Int. J. Med. Surg. Sci., 4(4):1241-1244, 2017.

Fig. 1. Fundus photo and Fluorescein angiography of left eye.
Fig. 2. OCT of macula.
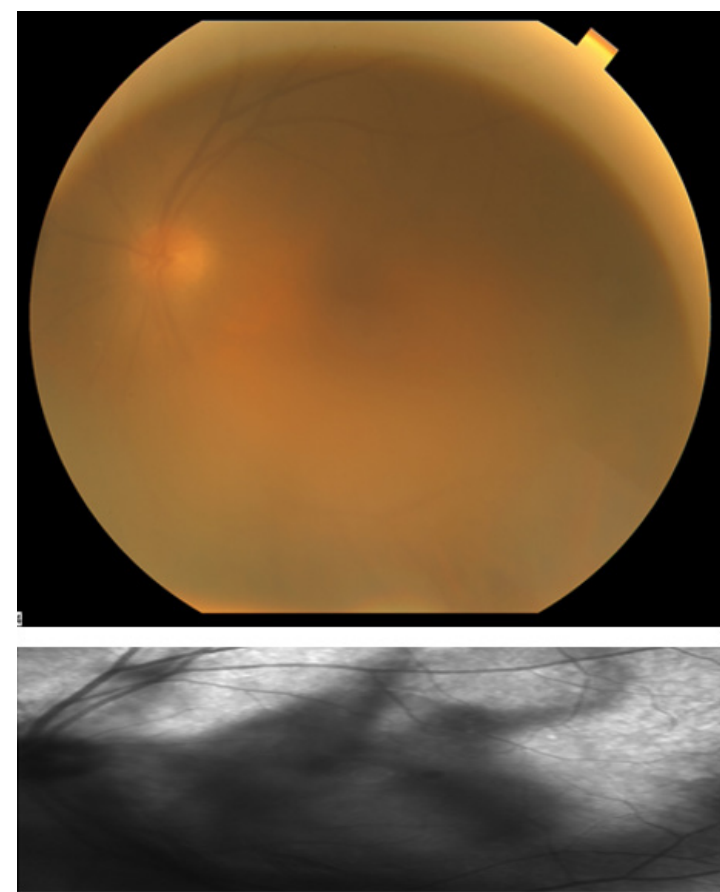

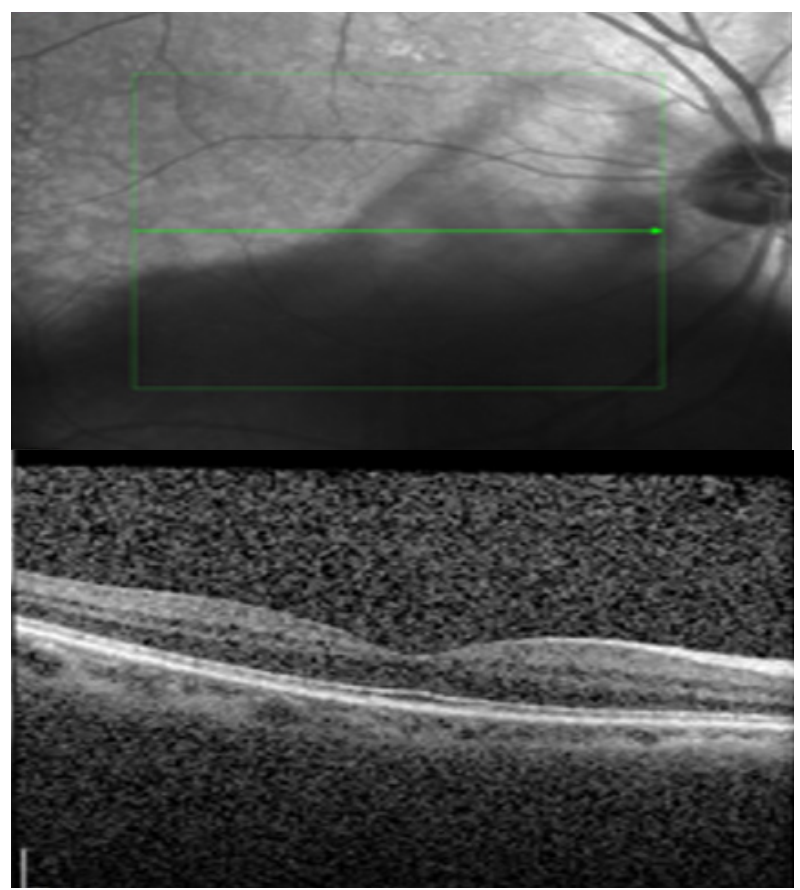

Fig. 3. Fundus photo and Fluorescein angiography of left eye.

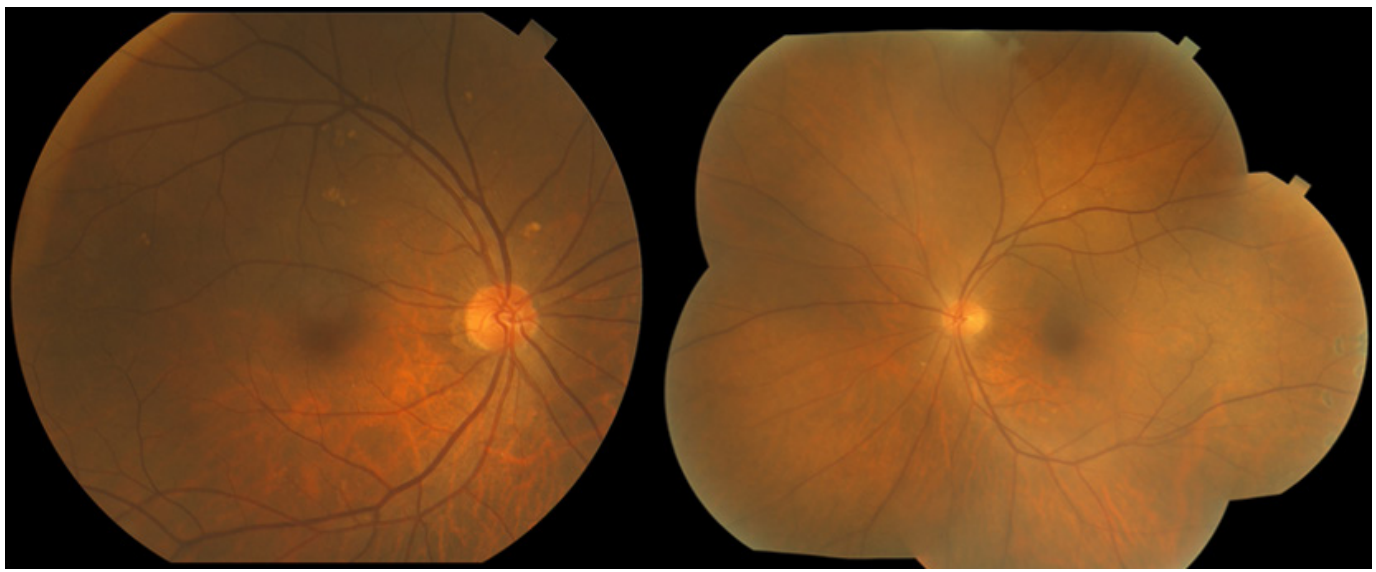

\section{CASE REPORT}

A 65-year-old Vietnamese male had one month of progressive blurred vision in both eyes and no other eye complaint. Other medical history revealed hypertension and high cholesterol. Through a careful history taking with the suspicion of the etiology revealed that one year previously, he had confusion and difficulty walking. The Imaging test was conducted and demonstrated a mass lesion of $(5.2 \times 5.0 \times 3.5 \mathrm{~cm}$ lesion) in the right frontal lobe with edema, involvement of corpus callosum, and $15 \mathrm{~mm}$ of $L$ to $R$ midline shift was noticed. After steroid treatment of the brain edema, he had stealth image guided left frontal brain biopsy showing diffuse large B-cell lymphoma (DLBCL), LDH 312, and confirmed the diagnosis of primary diffuse large $B$ cell lymphoma. He was treated with chemotherapy of Methotrexate $3.5 \mathrm{~g} / \mathrm{m}^{2}$ and cytarabine $2 \mathrm{mg} / \mathrm{m}^{2}$ and whole brain radiation therapy. There was a complete remission after the therapy.

Vision was OD 20/60, OS 20/200. Refraction: $-0.25+1.00 \times 118 \mathrm{OD},+0.50+0.75 \times 34$ OS. Intraocular pressure was $8.8 / 8.7$ measured by auto, non-contact tonometry.

Slit lamp exam each eye demonstrated a quiet anterior segment with no conjunctival injection and no anterior chamber cells or flare. There was 
$1+$ nucleus sclerotic cataract both eyes. Fundus of both eyes was partly obscured by cells mainly in the posterior vitreous. There appeared to be a few drusen in the right eye. Fundus photography and Fluorescein angiography showed no other abnormalities. (Figure 1) Optical Coherence Tomography (OCT) of each macula was normal. (Figure 2). It was felt that the patient had B cell lymphoma intraocular recurrence. We did not treat the patient with local chemotherapy using intravitreal Methotrexate (IMTX) (Helbig et al., 2003; Frenkel et al., 2008). Instead, as the hazy vision affected the patient's functional life style, sequential bilateral vitrectomies were done on $5 / 1 / 17$ and $7 / 17 / 17$ without complication. The vitreous sample from the first eye having vitrectomy was sent for study which demonstrated large B cell lymphoma. Post-op vision improved to $20 / 25$ without the complaint of hazy vision. (Figure 3 )

\section{DISCUSSION}

This case was diagnosed from a good history taking due to the suspicion of the masquerade syndrome. However, because of the malignant nature of this tumor and to differentiate from other causes vitritis, vitrectomy was indicated for the confirmation of the intraocular recurrence of lymphoma.

The vitrectomy dramatically improved the vision in one eye. Subsequently the second eye was also operated as requested by patient. There was no recurrent retina lesion detected after the vitreous were cleared in both eye. Frequent future oncological and ophthalmological follow up are essential to save this patient's eye sight and life.

In this patient recent follow up examination on $12 / 1 / 2017$ showed clear vitreous both eyes with $2+$ nucleus sclerosis cataracts. Vision best corrected was $20 / 50$ OD, 20/30 OS. He will be followed every three months.

\section{CONCLUSION}

Good history taking assisted in the diagnosis of intraocular lymphoma in this case with bilateral vitritis. However, bilateral vitrectomy restored the vision and further confirmed the diagnosis of lymphoma for future follow up care.

Chen, M. \& Drouilhet,J.H. Vitritis severa bilateral, una recurrencia intraocular de linfoma de células B: reporte de caso. Int. J. Med. Surg. Sci., 4(4):1241-1244, 2017.

RESUMEN: Objetivo: Reportar un caso de vitritis bilateral originada por un Linfoma del Sistema Nervioso Central Primario. El diagnóstico se realizó a partir de una cuidadosa historia clínica y confirmada con vitrectomía. Reporte de caso: Varón vietnamita de 65 años con un mes de visión borrosa progresiva en ambos ojos sin otra afección ocular. La historia reveló que hace aproximadamente un año, se le diagnosticó un linfoma difuso primario de células B grandes. Fue tratado con quimioterapia con Methotrexate $3.5 \mathrm{~g} /$ $\mathrm{m}^{2}$ y citarabina $2 \mathrm{mg} / \mathrm{m}^{2}$ y una radioterapia cerebral completa. Hubo una remisión completa después de la terapia. El fondo de ambos ojos estaba parcialmente oscurecido por las células, principalmente en el vítreo posterior. Las vitrectomías bilaterales secuenciales se realizaron el 5/1/17 y el 17/7/17 sin complicaciones. La muestra vítrea del primer ojo sometida a vitrectomía fue enviada a un estudio que demostró linfoma de células B grandes. La visión postoperatoria mejoró a 20/25 ambos ojos sin la queja de la visión borrosa. Conclusión: una buena historia clínica fue útil en el diagnóstico de linfoma intraocular en este caso con vitritis bilateral. Sin embargo, la vitrectomía bilateral restauró la visión y confirmó aún más el diagnóstico de linfoma para el cuidado de seguimiento futuro.

PALABRAS CLAVE: linfoma de células B grandes; linfoma intraocular; linfoma del sistema nervioso central; vitritis; uveítis.

\section{REFERENCES}

Chan, C.C., \& Wallace, D.J. Intraocular lymphoma: update on diagnosis and management. Cancer Control., 11:285-95, 2004.

DeAngelis, L.M., Seiferheld, W., Schold, S.C., Fisher, B., \& Schultz, C.J. Combination chemotherapy and radiotherapy for primary central nervous system lymphoma: Radiation Therapy Oncology GroupStudy 93-10. J Clin Oncol.,208(24):4643-8, 2002.
Frenkel, S., Hendler, K., Siegal, T., Shalom, E., \& Pe'er, J. Intravitreal methotrexate for treating vitreoretinal lymphoma: 10 years of experience. $\mathrm{Br}$ J Ophthalmol., 92:383-8, 2008.

Hormigo, A., \& DeAngelis, L.M. Primary ocular lymphoma: clinical features, diagnosis and treatment. Clin Lymphoma., 4:22-9, 2003. 
Chen, M. \& Drouilhet, J.H. Bilateral Severe Vitritis, an intraocular recurrence of B cell lymphoma: A case report. Int. J. Med. Surg. Sci., 4(4):1241-1244, 2017.

Hochberg, F.H., \& Miller, D.C. Primary central nervous system lymphomas. J Neurosurg., 68:83553, 1988.

Helbig, H., Cerny, T., \& de Smet, M.D. Intravitreal chemotherapy for intraocular lymphoma. Ophthalmologe., 100:145-9, 2003.

Panageas, K.S., Elkin, E.B., DeAngelis, L.M., BenPorat, L., \& Abrey, L.E. Trends in survival from primary central nervous system lymphoma, 1975-1999: a population-based analysis. Cancer., 104(11):2466-72, 2005.

Smith, J.R., Rosenbaum, J.T., Wilson, D.J., Doolittle, N.D., Siegal, T., Neuwelt, E.A., \& Pe'er, J. Role of intravitreal methotrexate in the management of primary central nervous system lymphoma with ocular involvement. Ophthalmology.,109:1709-16, 2002.

Wilson, D.J., Braziel, R., \& Rosenbaum, J.T. Intraocular lymphoma: immunopathologic. Analysis of vitreous biopsy specimens. Arch Ophthalmol.,110:1455-8, 1992.
Zamiri, P., Boyd, S., \& Lightman, S. Uveitis in the elderly-Is it easy to identify the masquerade? British J Ophthalmol., 81:827-31, 1997.

\section{Autor de correspondencia: \\ Ming Chen}

University of Hawaii, John A Burns School of Medicine, USA.

Tel.: (+1) 808-692-0899

E-mail: mingchen@hawaii.rr.com.

Conflictos de interés: None.

Financiamiento: None.

Recibido: 18-01-2018

Aceptado: 31-01-2018 